Personalidade Acadêmica Homenageada:

Augustus B. Cochran III (Agnes Scott College)

\title{
ABANDONADAS PELO ESTADO: A DURA REALIDADE DAS MULHERES MORADORAS DE RUA
}

\section{STATE ABANDONED: THE HARD REALITY OF STREET WOMEN}

MARIA FERNANDA VAZ OLIVEIRA

Graduanda em Direito, modalidade integral, pela Escola Superior Dom Câmara. Belo Horizonte-MG. Email: mariafe2810@hotmail.com.

\section{CAIO AUGUSTO SOUZA LARA}

Mestre e Doutor em Direito pela Faculdade de Direito da Universidade Federal de Minas Gerais - UFMG. Professor da Escola Superior Dom Helder Câmara. Pesquisador Associado ao Programa RECAJ-UFMG - Acesso à Justiça e Solução de Conflitos. Secretário de Comunicação do Conselho Nacional de Pesquisa e Pósgraduação em Direito - CONPEDI. Belo Horizonte-MG. E-mail: caiolarabh@yahoo.com.br.

\section{RESUMO}

O tema-problema da pesquisa que se pretende desenvolver é o abandono de mulheres moradoras de rua pelo Estado. Dessa forma, entende-se que as condições de existência dessas pessoas são marcadas pela irregularidade da frequência de refeições saudáveis, pelo constante preconceito, pelo risco de contração de doenças e pela exposição às condições climáticas enfrentadas no diadia da população sem teto. Além disso, por não possuírem voz no cenário político, esses grupos acabam tendo seus direitos postos em segundo plano; o lugar de fala das mulheres em situação de rua não é respeitado e a busca por mais representatividade deve ser uma luta constante não só na vida social, mas na vida 


\section{Personalidade Acadêmica Homenageada:}

\section{Augustus B. Cochran III (Agnes Scott College)}

política principalmente. Ademais, a vontade de sair da condição de sem-teto é comum para a grande maioria delas, que ainda procuram no mercado de trabalho uma forma de garantir renda fixa. Porém, as barreiras sociais ocasionadas pelo machismo agravam ainda mais a mudança de vida. O problema objeto da investigação científica proposta é: como o governo negligencia a garantia dos direitos fundamentais de mulheres em situação de rua no Brasil? A partir das reflexões preliminares sobre o tema, é possível afirmar inicialmente que o Estado não garante direitos essenciais às mulheres moradoras de rua, ao não promover políticas públicas efetivas nesta seara. Percebe-se que as ações com intuito de prestar assistência a essas pessoas em situações de abuso sexual, agressões, inserção no mercado de trabalho, gestação e fornecimento de itens básicos de higiene pessoal, são de responsabilidade estatal. Contudo, compreende-se que as mulheres nessas situações encontram-se invisíveis ao sistema social de proteção, principalmente pela falta de intervenção em circunstâncias de risco às suas integridades física e mental. O objetivo geral do trabalho é analisar como as mulheres em situação de rua têm seus direitos básicos negados pelo Estado, demonstrando como o machismo estrutural dificulta a saída das ruas e entendendo como as mulheres, sendo um grupo de minorias, inserem-se em outro grupo de minorias, o dos moradores de rua. A pesquisa que se propõe pertence à vertente metodológica jurídico-sociológica. No tocante ao tipo de investigação, foi escolhido, na classificação de Witker (1985) e Gustin (2010), o tipo jurídico-projetivo. raciocínio desenvolvido na pesquisa será predominantemente dialético. De acordo com a técnica de análise de conteúdo, afirma-se que trata-se de uma pesquisa teórica, o que será possível a partir da análise de conteúdo dos textos doutrinários, normas e demais dados colhidos na pesquisa. A partir do exposto, conclui-se que o regime governamental brasileiro demonstra desinteresse proposital em relação a situação dos indivíduos em situação de rua. Por essa razão, os índices apontam a incapacidade de abrigos com iniciativa pública em atender tamanho contingente populacional sem-teto. Outrossim, o não fornecimento de água potável a partir de bebedouros públicos nas grandes cidades concretiza ainda mais a negligência de órgãos estatais. De acordo com os argumentos supracitados, sabe-se que o 


\section{Personalidade Acadêmica Homenageada:}

\section{Augustus B. Cochran III (Agnes Scott College)}

machismo estrutural, enraizado na sociedade patriarcal, transforma as mulheres moradoras de rua em "objetos", de forma que agressões físicas e psicológicas sofridas por essas pessoas não são tratadas com a seriedade que a situação demanda, formando assim, um ciclo vicioso. Entretanto, nota-se que pequenas iniciativas já foram tomadas para a tentativa de resolver os problemas, o que implica a capacidade formal e o descaso estatal em adotar medidas não efetivas. Portanto, o capitalismo, como o sistema vigente, apenas impulsiona essa perspectiva, com seu individualismo e egoísmo na convivência passiva constante com a condição, não apresentando soluções práticas e assinando uma "sentença de morte" dos valores democráticos e dos direitos fundamentais imprescindíveis, como o direito à dignidade e à moradia.

PALAVRA-CHAVE: Moradores de rua; Mulheres; Direitos Fundamentais; Políticas Públicas.

\section{REFERÊNCIAS}

BOBBIO, Norberto. A Era dos Direitos. Tradução Carlos Nelson Coutinho. Rio de Janeiro: Elservier 1992.

CAMPOS, Ana Maria Gambier et al. População de rua: pesquisa social participativa. Curitiba: Juruá Editora 2018.

GUSTIN, Miracy Barbosa de Sousa; DIAS, Maria Tereza Fonseca. (Re)pensando a pesquisa jurídica: teoria e prática. 3aㅗ. ed. Belo Horizonte: Del Rey, 2010.

JESUS, Maria Carolina de. Antologia Pessoal. Rio de Janeiro: Editora UFRJ, 1996.

RUIZ, Ivan Aparecido; PINTO, Tatiana Coutinho Pita. Da violência psíquica contra a mulher e sua proteção insuficiente na ordem jurídica brasileira. Revista Jurídica UNICURITIBA, Curitiba, v. 2, n. 29, p. 285-307, 2012. Disponível em: http://revista.unicuritiba.edu.br/index.php/RevJur/article/view/524/408. Acesso em: 20 maio 2019. 
Personalidade Acadêmica Homenageada:

Augustus B. Cochran III (Agnes Scott College)

TIBURI, Marcia. Lugar de fala e lugar e dor. Cult. São Paulo, 29 mar. 2017. Disponível em: https://revistacult.uol.com.br/home/lugar-de-fala-e-etico-politica-daluta/. Acesso em: 07 maio 2019.

TIBURI, Marcia. Ninguém mora onde não mora ninguém. Cult. São Paulo, 10 mar. 2011. Disponível em: https://revistacult.bigfishhost.com.br/ninguem-mora-onde-naomora-ninguem/. Acesso em: 07 maio 2019.

TIENE, Izalene. Mulher moradora de rua: entre vivências e políticas sociais. Campinas: Alínea, 2004.

WITKER, Jorge. Como elaborar una tesis en derecho: pautas metodológicas y técnicas para el estudiante o investigador del derecho. Madrid: Civitas, 1985. 